\title{
HUBUNGAN PENERAPAN PROSES KEPERAWATAN IDA JEAN ORLANDO \\ TERHADAP PENINGKATAN KUALITAS PELAYANAN DI RUANG PERAWATAN KRITIS IGD DAN ICU RSUD KABUPATEN PANGKAJENE DAN KEPULAUAN
}

\author{
Relationship Of The Implementation Of Nursing Ida Jean Orlando's Process \\ On Improving The Quality Of Service In The Critical Care Unit And \\ Intensive Care Unit Of RSUD Kabupaten pangkajene And Islands
}

\author{
Amanah Restuyana Zainal, Julianus Ake, Syahrir Pasinringi \\ Program Studi Magister Ilmu Keperawatan Universitas Hasanuddin Makassar \\ Email: amanahrestuyana@ymail.com
}

\begin{abstract}
ABSTRAK
Perawat sebagai salah satu tenaga kesehatan di rumah sakit memegang peranan penting dalam upaya mencapai tujuan pembangunan kesehatan. Keberhasilan pelayanan kesehatan bergantung pada partisipasi perawat dalam memberikan asuhan keperawatan yang berkualitas bagi pasien, agar dapat mewujudkan pelayanan yang berkualitas dan berkinerja tinggi diperlukan tenaga keperawatan yang profesional, memiliki kemampuan intelektual, teknikal interpersonal, bekerja berdasarkan standar praktik, serta memperhatikan kaidah etik dan moral. Salah satu model penerapan asuhan keperawatan yang terbaik adalah memberikan respon segera terhadap pasien, ini dapat meningkatkan kualitas pelayanan keperawatan melalui penilaian kepuasan pasien terhadap perawat sebagai salah satu indikator mutu pelayanan. Tujuan penelitian ini adalah untuk mengetahui hubungan penerapan proses keperawatan Ida Jean Orlando dengan peningkatan kualitas pelayanan di Ruang Perawatan Kritis IGD dan ICU RSUD Kabupaten Pangkajene dan Kepulauan.Desain penelitian ini menggunakan metodeCross Sectional, metode sampling yang digunakan adalah Purposive Sampling. Sampel sejumlah 56 perawat dan 129 pasien yang memenuhi kriteria inklusi. Variabel yang diteliti adalah variabel independent yaitu proses keperawatan : tanggung jawab perawat, mengenal perilaku pasien, reaksi segera, disiplin dalam keperawatan dan evaluasi kemajuan kondisi pasien, variabel dependent yaitu kepuasan pasien. Data dikumpulkan menggunakan kuesioner dan dianalisis dengan menggunakan uji statistik Korelasi Regresi Linear dengan tingkat kemaknaan 0.05. Hasil penelitian menunjukkan bahwa perawat dalam melaksanakan tanggung jawab dengan cukup baik sebesar $87.60 \%$, perawat mengenal perilaku dengan baik sebesar $68.99 \%$, perawat yang memberikan reaksi segera dengan baik sebanyak $56.59 \%$, perawat telah melaksanakan disiplin dalam asuhan keperawatan dengan baik sebesar 56.59\%, dan perawat yang mengevaluasi kemajuan kondisi pasien dengan baik sebesar 90.70\%. Data kepuasan pasien sebesar $75.81 \%$ berdasarkan perhitungan Indeks Kepuasan Masyarakat dengan mutu pelayanan keperawatan dinilai baik. Hasil uji statistik regresi linear, menunjukkan nilai sig.p=0.000 ( $\mathrm{p}<0.05)$. Dari hasil penelitian ini, RSUD Kabupaten Pangkajene dan Kepulauan dapat lebih meningkatkan kualitas pelayanan dengan lebih
\end{abstract}


meningkatkan pelayanan keperawatan di ruang perawatan kritis atau di ruang pelayanan lainnya dengan menitikberatkan pada proses keperawatan segera.

Kata kunci : Proses Keperawatan Orlando, Kepuasan Pasien, Ruang Perawatan Kritis IGD dan ICU

\section{ABSTRACT}

Nurses as one of the health workers in hospitals play an important role in efforts to achieve health development goals. The success of health services depends on the participation of nurses in providing quality nursing care for patients, in order to realize high-quality and high-performance services that are required by professional nursing staff, have intellectual, interpersonal technical abilities, work according to standard practice, and pay attention to ethical and moral principles. One of the best models of the application of nursing care is to provide an immediate response to patients, this can improve the quality of nursing services through the assessment of patient satisfaction with nurses as one indicator of service quality. The purpose of this study was to determine the relationship between the application of Ida Jean Orlando's nursing process and improving the quality of service in the Critical Care Room of the ED and ICU at Pangkajene and Islands District Hospital. The design of this study used Cross Sectional method, the sampling method used was purposive sampling. A sample of 56 nurses and 129 patients who met the inclusion criteria. The variables studied were independent variables, namely the nursing process: nurse's responsibility, recognizing patient behavior, immediate reaction, discipline in nursing and evaluating the progress of the patient's condition, the dependent variable was patient satisfaction. Data were collected using a questionnaire and analyzed by using the Linear Regression Correlation statistical test with a significance level of 0.05 . The results showed that nurses in carrying out their responsibilities quite well at $87.60 \%$, nurses knew good behavior at $68.99 \%$, nurses who reacted immediately well as much as $56.59 \%$, nurses had implemented discipline in nursing care well by $56.59 \%$, and nurses who evaluate the progress of the patient's condition well are $90.70 \%$. Patient satisfaction data is $75.81 \%$ based on the calculation of the Community Satisfaction Index with the quality of nursing services considered good. The results of the linear regression statistical test show the value of sig.p $=0.000(p<0.05)$. From the results of this study, the Pangkajene and Kepulauan District Public Hospital can further improve the quality of services by further improving nursing services in critical care rooms or in other service spaces by focusing on the nursing process immediately.

Keywords: Orlando Nursing Process, Patient Satisfaction, Emergency Room Critical Care and ICU

\section{PENDAHULUAN}

Keperawatan di Indonesia, masih terus mengembangkan diri sebagai profesi yang dalam jangka panjang diharapkan mampu memenuhi tuntutan dan harapan masyarakat
(Nursalam, 2016). Sejalan dengan adanya Undang-Undang Keperawatan Nomor 38 tahun 2014 yang menjelaskan tentang praktik keperawatan, bentuk pelayanan yang diselenggarakan oleh perawat adalah 
asuhan keperawatan yang terdiri dari pengkajian, penetapan diagnosa keperawatan, perencanaan, implementasi, dan evaluasi. Bentuk pelayanan inilah yang merupakan satu rangkaian proses keperawatan yang merupakan dasar dari asuhan keperawatan baik terhadap pasien sebagai individu, keluarga ataupun masyarakat (Presiden Republik Indonesia, 2014).

Di dalam melaksanakan tugasnya, perawat selalu mengacu kepada Standar Prosedur Operational (SPO) yang berlaku, agar mendapatkan jaminan kerja dan keamanan dalam bekerja, sehingga masyarakat dapat merasakan pelayanan yang berkualitas atau memberikan kepuasan tersendiri bagi masyarakat, seperti yang dikutip dari hasil penelitian Kurniati dan Abidin (2018).

Berdasarkan UU Nomor 44 Tahun 2009 tentang Rumah Sakit yang menjelaskan tentang 18 Hak Pasien dan Keluarga selama berada di RS, menghormati dan melindungi hak-hak pasien, dimana salah satu hak pasien adalah "Memperoleh layanan kesehatan yang bermutu sesuai dengan standar profesi dan standar prosedur operasional" sehingga sangatlah penting bagi para Profesi Pemberi Asuhan (PPA) untuk memberikan pelayanan yang bermutu, khususnya perawat dalam memberikan asuhan keperawatan yang terbaik kepada pasien dan keluarga pasien.

Kepuasan Masyarakat sebagai tolak ukur keberhasilan

penyelenggaraan pelayananyang merupakan ukuran untuk menilai kualitas layanan public, sehingga setiap tahunnya pemerintah mengevaluasi peraturan perundang-undangan yang berlaku sesuai dengan kebutuhan masyarakat dan target yang akan dicapai, mulai dari Keputusan MENPAN Nomor 25 tahun 2004, Peraturan MENPANRB Nomor 16 tahun 2014 sampai kepada
Peraturan MENPANRB Nomor 14 tahun 2017 yang mengatur tentang Survey Kepuasan Masyarakat.

Perawat melaksanakan asuhan keperawatan berdasarkan kewenangan klinis yang dimiliki dari jenjang kariernya dan berdasarkan unit keperawatan yang ditempatinya. Proses asuhan keperawatan yang dilaksanakan juga berbeda berdasarkan unit kerja masing-masing, seperti proses keperawatan di ruang rawat inap berbeda dengan proses keperawatan di perawatan kritis ataupun di instalasi rawat jalan. Dari data yang didapatkan di RS, dalam upaya peningkatan mutu pelayanan, maka dapat diprioritaskan kepada pelayanan keperawatan kepada pasien, terutama di perawatan kritis seperti IGD dan ICU yang masih rendah capaian kepuasan pasiennya.

Dalam bidang keperawatan, terdapat teori keperawatan yang aplikatif dan dapat diterapkan di ruang perawatan kritis IGD dan ICU yaitu asuhan keperawatan berdasarkan aplikasi dari Teori Ida Jean Orlando, teori keperawatan ini adalah salah satu bentuk penerapan asuhan keperawatan yang dapat digunakan karena sangat memperhatikan tanggungjawab perawat dalam memberikan pelayanan, mengenal perilaku pasien, memberikan reaksi segera dalam melayani pasien, disiplin dalam proses keperawatan dan mengontrol kemajuan/peningkatan kondisi pasien. Dengan penerapan proses keperawatan Orlando di ruang perawatan kritis IGD dan ICU, maka diharapkan pasien dapat dilayani dengan baik dan memberikan penilaian positif bagi perawat yang bekerja dan bagi RS.

Dengan memberikan asuhan keperawatan yang tepat, diharapkan kualitas pelayanan keperawatan dapat meningkat, khususnya 
di perawatan kritis IGD dan ICU., berdasarkan hal tersebut, maka penelitian ini berfokus pada hubungan penerapan proses keperawatan Ida Jean Orlando dengan peningkatan kualitas pelayanan keperawatan di ruang perawatan kritis IGD dan ICU RSUD Kabupaten Pangkajene dan Kepulauan.

\section{METODE}

Desain penelitian atau rancangan penelitian yang digunakan dalam penelitian ini adalah penelitian korelasional. Penelitian ini bertujuanmencari, menjelaskan suatu hubungan korelatif antarvariabel dan menguji berdasarkan teori yang ada. Desain penelitian yang digunakan dalam penelitian ini adalah deskriptif analitik dengan pendekatan cross sectional studyyaitu menekankan waktu pengukuran/observasi data variabel independen dan dependen hanya satu kali pada satu saat (Nursalam,2013)

Untuk hasil survey kepuasan pasien, metode analisisnya menggunakan Statistik deskriptif dan uji korelasi Regresi Linear serta perhitungan IKM sesuai dengan KepmenPAN \& RB

Penelitian ini dilakukan di ruang Perawatan Kritis IGD dan ICU Rumah Sakit Umum Daerah Pangkajene dan Kepulauan. Waktu penelitian ini dilakukan pada bulan Mei 2017s/d Juni 2018, dimulai dari penulisan proposal, pengumpulan data, penulisan laporan penelitian.

Sampel dalam penelitian ini adalah perawat pelaksana ruang rawat inap RSUD Kabupaten Pangkajene dan Kepulauan yang dinilai oleh kepala ruangan. Jumlah sampel dalam penelitian ini sebanyak 56 perawat dan 129 pasien. Adapun analisis data yang digunakan adalah Uji Korelasi Regresi Linear dengan signifikasi 0.05 dengan menggunakan SPSS 22.0

\section{HASIL DAN PEMBAHASAN}

Hasil

\section{1) Tanggungjawab Perawat}

Tabel 1: Tanggung jawab perawat

\begin{tabular}{cccccccc}
\hline & \multicolumn{4}{c}{ Tanggung Jawab Perawat } \\
$\begin{array}{c}\text { Respond } \\
\text { en }\end{array}$ & \multicolumn{2}{c}{$\begin{array}{c}\text { Kurang } \\
\text { Baik }\end{array}$} & \multicolumn{2}{c}{ Cukup } & \multicolumn{2}{c}{ Baik } & \multicolumn{2}{c}{ Baik } \\
& $\mathrm{n}$ & $\%$ & $\mathrm{n}$ & $\%$ & $\mathrm{n}$ & $\%$ \\
\hline 129 & 4 & 3,10 & 113 & 87,6 & 12 & 9,3
\end{tabular}

Tabel di atas menunjukkan bahwa karakteristik perawat yang memiliki persepsi tanggungjawab dalam kategori kurang baik sebesar 3.10\%, kategori cukup baik sebesar $87.60 \%$ dan kategori baik sebesar $9.30 \%$.

\section{2) Mengenal Perilaku Pasien}

Tabel 2: Perilaku Pasien

\begin{tabular}{cccccccc}
\hline & \multicolumn{4}{c}{ Mengenal Perilaku Pasien } \\
\multirow{2}{*}{$\begin{array}{c}\text { Respond } \\
\text { en }\end{array}$} & \multicolumn{2}{c}{$\begin{array}{c}\text { Kurang } \\
\text { Baik }\end{array}$} & \multicolumn{2}{c}{ Cukup } & \multicolumn{2}{c}{ Baik } & \multicolumn{2}{c}{ Baik } \\
& $\mathrm{n}$ & $\%$ & $\mathrm{n}$ & $\%$ & $\mathrm{n}$ & $\%$ \\
\hline 129 & 0 & 0, & 40 & 31,01 & 89 & 68,99 \\
\hline
\end{tabular}

Tabel di atas menunjukkan bahwa karakteristik perawat yang memiliki persepsi dalam Mengenal Perilaku Pasien, kategori cukup baik sebesar 31.01\%, kategori baik sebesar $68.99 \%$

\section{3) Reaksi Segera}

Tabel 3: Reaksi segera perawat

\begin{tabular}{|c|c|c|c|c|c|c|}
\hline \multirow{3}{*}{$\begin{array}{c}\text { Respo } \\
\text { nden }\end{array}$} & \multicolumn{6}{|c|}{ Reaksi Segera } \\
\hline & \multicolumn{2}{|c|}{$\begin{array}{c}\text { Kurang } \\
\text { Baik }\end{array}$} & \multicolumn{2}{|c|}{ Cukup Baik } & \multicolumn{2}{|c|}{ Baik } \\
\hline & $\mathrm{n}$ & $\%$ & $\mathrm{n}$ & $\%$ & $\mathrm{n}$ & $\%$ \\
\hline 129 & 0 & 0 & 56 & 43,41 & 73 & 56,59 \\
\hline
\end{tabular}

Tabel di atas menunjukkan bahwa karakteristik perawat terhadap reaksi segera dalam melakukan tindakan ke pasien, yang termasuk dalam kategori cukup baik 
sebesar $43.41 \%$ dan kategori baik sebesar $56.59 \%$.

\section{4) Disiplin dalam Proses Keperawatan}

Tabel4: Disiplin dalam proses keperawatan

\begin{tabular}{ccccccc}
\multirow{2}{*}{$\begin{array}{c}\text { Respon } \\
\text { den }\end{array}$} & \multicolumn{2}{c}{ Disiplin dalam Asuhan Keperawatan } \\
& \multicolumn{2}{c}{$\begin{array}{c}\text { Baik } \\
\text { nuang }\end{array}$} & \multicolumn{2}{c}{$\begin{array}{c}\text { Cukup } \\
\text { Baik }\end{array}$} & \multicolumn{2}{c}{ Baik } \\
& $\mathrm{n}$ & $\%$ & $\mathrm{n}$ & $\%$ \\
\hline 129 & 0 & 0,00 & 56 & 43,41 & 73 & 56,59 \\
\hline
\end{tabular}

Tabel di atas menunjukkan bahwa karakteristik perawat yang melaksanakan disiplin dalam proses keperawatan, yang termasuk dalam kategori cukup baik sebesar $43.41 \%$ dan kategori baik sebesar $56.59 \%$.

\section{5) Mengenal Kemajuan/Peningkatan}

\section{Kondisi Pasien}

Tabel 5: Mengenal Kemajuan/Peningkatan Kondisi Pasien

\begin{tabular}{ccccccc}
\hline \multirow{2}{*}{$\begin{array}{c}\text { Respond } \\
\text { en }\end{array}$} & \multicolumn{2}{c}{ Evaluasi Kemajuan Kondisi Pasien } \\
& \multicolumn{2}{c}{ Kuik } & \multicolumn{2}{c}{ Cukup } & \multicolumn{2}{c}{ Baik } \\
& $\mathrm{n}$ & $\%$ & $\mathrm{n}$ & $\%$ & $\mathrm{n}$ & $\%$ \\
\hline 129 & 0 & 0,0 & 12 & 9,30 & 117 & 90,70 \\
\hline
\end{tabular}

Tabel di atas menunjukkan bahwa karakteristik perawat yang memiliki persepsi untuk mengenal kemajuan kondisi pasien yang dirawat adalah sebanyak $9.30 \%$ yang termasuk dalam kategori cukup baik dan sebanyak $90.70 \%$ dalam kategori baik.

\section{6) Analisis Persepsi Responden terhadap Mutu Pelayanan Keperawatan berdasarkan Indeks Kepuasan Masyarakat (IKM)}

Tabel 6: Rata-Rata Kepuasan Pasien terhadap Mutu Pelayanan Keperawatan di Unit Khusus IGD dan ICU RSUD

Kabupaten Pangkajene dan Kepulauan

$\begin{array}{cccc} & \text { Rata- } & & \text { Nilai } \\ \text { Unsur } & \text { Rata } & \text { Nilai } & \text { Indeks } \\ \text { Pelayanan } & \text { Nilai } & \text { Tertim- } & \text { Unit } \\ & \text { Unsur } & \text { bang } & \text { Pelaya } \\ & \begin{array}{c}\text { Pelaya- } \\ \text { nan }\end{array} & & \text { nan }\end{array}$

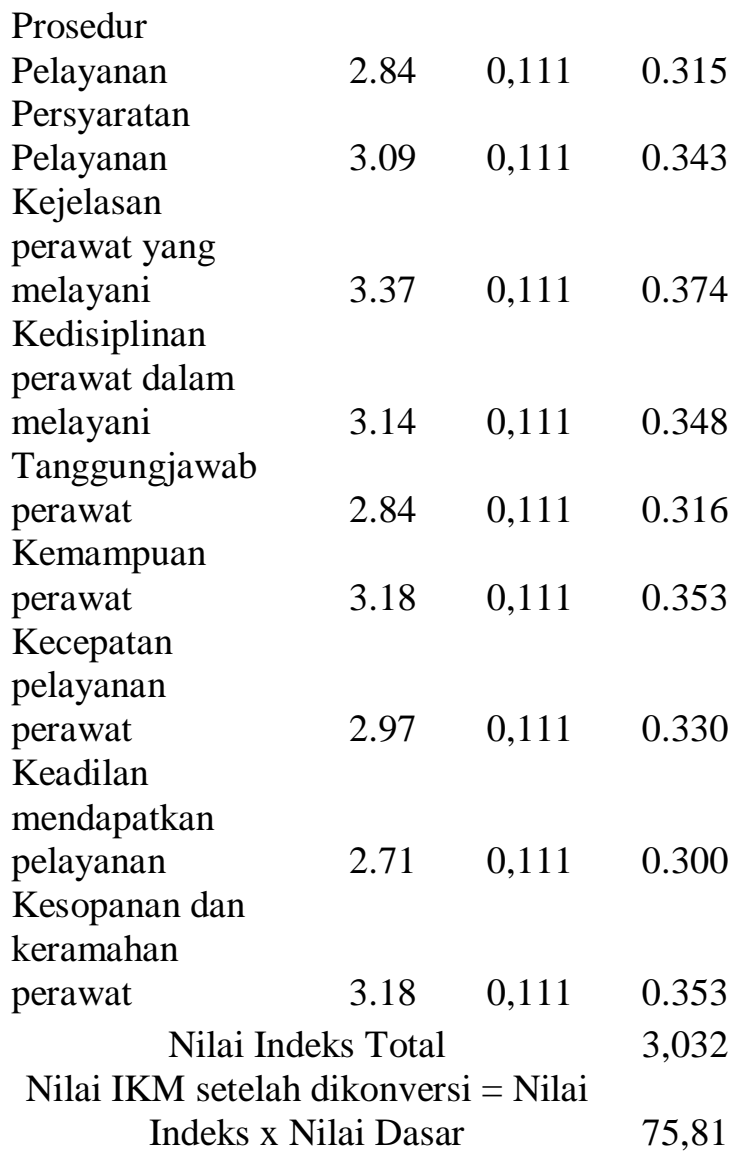

Tabel di atas menunjukkan bahwa di unit khusus IGD dan ICU, memiliki mutu pelayanan baik dengan nilai IKM 75,81 , dimana nilai unsur yang paling baik adalah kejelasan perawat dalam melayani yaitu sebesar 3,37. Namun yang harus menjadi perhatian utama adalah 3 unsur terendah, yaitu prosedur pelayanan $(2,84)$, tanggung jawab perawat (2.84), dan keadilan dalam mendapatkan pelayanan $(2,71)$. 
7) Uji Korelasi Antara Proses Keperawatan Orlando dengan

\section{Kepuasan Pasien}

Tabel 7: Hasil Analisis Pearson

Correlation Antara Proses Keperawatan

Orlando dengan Kepuasan Pasiendi Ruang

Perawatan Kritis IGD dan ICU RSUD

Kabupaten Pangkajene dan Kepulauan

\begin{tabular}{lcc}
\hline Proses Keperawatan & Nilai $\boldsymbol{p}$ & Nilai $\boldsymbol{r}$ \\
\hline Tanggungjawab & 0.000 & 0.692 \\
perawat & $(p<\alpha)$ & 0,585 \\
Mengenal Perilaku & 0,000 & 0,813 \\
Pasien & $(p<\alpha)$ & \\
Reaksi Segera & 0,000 & \\
& $(p<\alpha)$ & \\
Disiplin dalam Proses & 0,000 & 0,519 \\
Keperawatan & $(p<\alpha)$ & \\
Kemajuan/Peningkatan & 0,000 & 0,755 \\
Kondisi Pasien & $(p<\alpha)$ & \\
\hline
\end{tabular}

Hasil analisis bivariat berdasarkan uji korelasi Pearsonmenunjukkan bahwa proses keperawatan yang terdiri dari tanggungjawab perawat, mengenal perilaku pasien, disiplin dalam proses keperawatan dan evaluasi kemajuan peningkatan kondisi pasien terhadap mutu pelayanan keperawatan melalui survey kepuasan pasien, memiliki hubungan yang kuat dari kelima variabel independent terhadap variabel dependent, dimana nilai signifikansi $0.000(p<0,05)$. Selain itu, tabel di atas juga menunjukkan bahwa korelasi yang paling tinggi adalah rekasi segera $(\mathrm{r}=0.813)$, kemudian hubungan yang paling kuat berikutnya adalah evaluasi kemajuan kondisi pasien $(\mathrm{r}=0.755)$, tanggungjawab perawat $(\mathrm{r}=0.692)$, mengenal perilaku pasien $(\mathrm{r}=0.585)$ dan hubungan yang paling lemah adalah disiplin dalam asuhan keperawatan $(\mathrm{r}=519)$.
8) Resume Analisis Regresi Linear Antara Tanggung Jawab Perawat, Mengenal Perilaku Pasien, Reaksi Segera, Disiplin dalam Keperawatan dan Kemajuan Kondisi Pasien dengan Kepuasan Pasien di ruang Perawatan Kritis IGD dan ICU RSUD Kabupaten Pangkajene Dan Kepulauan

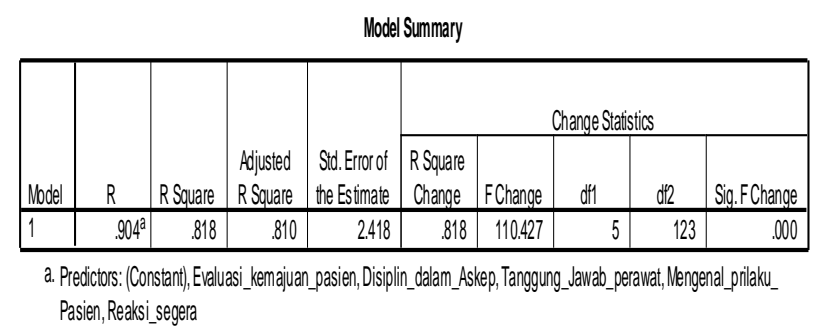

Tabel di atas menjelaskan bahwa $\mathrm{R}$ Square merupakan besarnya kepuasan pasien terhadap 5 sub variabel : tanggung jawab perawat, mengenal perilaku pasien, reaksi segera, disiplin dalam keperawatan dan evaluasi kemajuan kondisi pasien adalah sebesar $81.8 \%$.

9) Uji FAntara Tanggung Jawab Perawat, Mengenal Perilaku Pasien, Reaksi Segera, Disiplin dalam Keperawatan dan Kemajuan Kondisi Pasien dengan Kepuasan Pasien di ruang Perawatan Kritis IGD dan ICU RSUD Kabupaten Pangkajene Dan KepulauaneNovab

\begin{tabular}{|c|c|c|c|c|c|c|}
\hline Model & & $\begin{array}{l}\text { Sum of } \\
\text { Squares }\end{array}$ & $d f$ & Mean Square & $F$ & Sig. \\
\hline \multirow[t]{3}{*}{1} & Regression & 3227.072 & 5 & 645.414 & 110.427 & $.000^{a}$ \\
\hline & Residual & 718.897 & 123 & 5.845 & & \\
\hline & Total & 3945.969 & 128 & & & \\
\hline
\end{tabular}

a. Predictors: (Constant), Evaluasi_kemajuan_pasien, Disiplin_dalam_Askep, Tanggung_Jawab_perawat, Mengenal_prilaku_Pasien, Reaksi_segera

b. Dependent Variable:Kepuasan_pasien 
Tabel di atas menjelaskan bahwa variabel kepuasan pasien signifikan $\mathrm{p}<$ 0.05 berkorelasi linear dengan kelima sub variabel dari proses keperawatan Orlando dengan nilai F hitung 110.427

10) Uji tAntara Tanggung Jawab Perawat, Mengenal Perilaku Pasien, Reaksi Segera, Disiplin dalam Keperawatan dan Kemajuan Kondisi Pasien dengan Kepuasan Pasien di ruang Perawatan Kritis IGD dan ICU RSUD Kabupaten Pangkajene Dan Kepulauan

\begin{tabular}{|c|c|c|c|c|c|c|c|c|c|}
\hline \multirow[b]{2}{*}{ Model } & & \multicolumn{2}{|c|}{$\begin{array}{l}\text { Unsiandadadized } \\
\text { Coeficientis }\end{array}$} & \multirow{2}{*}{$\begin{array}{c}\text { Standardized } \\
\text { Coeticicients } \\
\text { Beta }\end{array}$} & \multirow[b]{2}{*}{$t$} & \multirow[b]{2}{*}{ Sig. } & \multicolumn{3}{|c|}{ Correlations } \\
\hline & & $B$ & Sto. Error & & & & Zero-order & Partial & Patt \\
\hline 1 & (Constantit) & .29 .638 & 2.796 & & .10 .599 & .000 & & & \\
\hline & $\begin{array}{l}\text { Tangoung_avwab_ } \\
\text { perawat }\end{array}$ & .380 & .070 & .268 & 5.400 & .000 & .692 & .438 & .208 \\
\hline & $\begin{array}{l}\text { Nengenal prilaku_ } \\
\text { Pasien }\end{array}$ & .799 & .236 & .168 & 3.390 & .001 & .585 & .292 & .130 \\
\hline & Reaksis segera & .897 & .113 & .441 & 7.944 & .000 & .813 & .582 & .306 \\
\hline & Disipin__alam_Askep & .061 & .090 & .033 & .672 & .503 & .519 & .061 & .026 \\
\hline & $\begin{array}{l}\text { Evaluasi Kemajuan_ } \\
\text { pasien }\end{array}$ & 1.038 & .286 & .210 & 3.636 & .000 & .755 & .312 & .140 \\
\hline
\end{tabular}

a. Dependent Variade: Kepluasan _pasien

Tabel di atas menunjukkan bahwa melalui persamaan regresi $-29.638+0.380 *$ tanggung jawab perawat $+0.799 *$ mengenal perilaku pasien $+0.897 *$ reaksi segera $+0.061 *$ disiplin dalam keperawatan $+1.038^{*}$ evaluasi kemajuan pasien. Maknanya adalah, ketika variabel mengenal perilaku pasien, reaksi segera, disiplin dalam keperawatan dan evaluasi kemajuan pasien konstant, maka tingkat kepuasan pasien akan meningkat sebesar 0.380 dengan meningkatnya setiap satu satuan tanggung jawab perawat.

Tabel $t$ menunjukkan urutan kontribusi variabel, dimana reaksi segera perawat lebih besar hubungannya/pengaruhnya dibandingkan dengan variabel lainnya, yaitu tanggung jawab perawat, evaluasi kemajuan pasien, mengenal perilaku pasien dan yang paling kecil hubungannya/pengaruhnya adalah disiplin dalam asuhan keperawatan.

\section{Pembahasan}

1. Analisis Tanggung jawab perawat terhadap kepuasan pasien di Ruang Perawatan Kritis IGD dan ICU RSUD Kabupaten Pangkajene dan Kepulauan

Hasil penelitian mengenai tanggung jawab perawat di ruang perawatan kritis IGD dan ICU RSUD Kabupaten Pangkaejne dan Kepulauan, menunjukkan bahwa sebagian besar perawat melaksanakan tanggung jawab dengan cukup baik sebesar $87.60 \%$, namun masih terdapat perawat yang memiliki tanggung jawab kurang sebesar $3.10 \%$ dan terdapat pula perawat yang melaksanakan tanggung jawabnya dengan baik sebesar $9.30 \%$. Hal ini menjelaskan bahwa sebagian besar perawat di ruang perawatan kritis, melaksanakan tugas dengan cukup baik, namun masih perlu ditingkatkan dalam hal respon dan rasa peduli terhadap pasien, tidak hanya sekadar menjalankan kewajiban, tapi seharusnya perawat lebih menunjukkan sikap peduli mulai pasien masuk di ruangan sampai pasien dipindahkan ke ruang rawat.

Tanggung jawab merupakan aspek penting dalam membangun etika perawat. Tanggung jawab adalah kesediaan seseorang untuk menyiapkan diri dalam menghadapi risiko terburuk sekalipun, memberikan kompensasi atau informasi terhadap tugas-tugas yang telah dilaksanakan. Perawat berkewajiban untuk bertanggung jawab terhadap setiap tindakan yang dilakukan, seperti tanggung jawab perawat selama bertugas, melakukan 
operan pasien dengan baik, melakukan prosedur keperawatan dengan baik ke pasien, bertanggung jawab dalam melakukan pendokumentasian asuhan keperawatan, bertanggung jawab dalam menjaga keselamatan pasien, dalam mengobservasi kondisi perkembangan pasien. Tanggung jawab perawat, erat kaitannya dengan tugas-tugas perawat dimana tugas perawat secara umum adalah memenuhi kebutuhan dasar pasien. Perawat diharapkan memandang pasien sebagai makhluk yang unik dan komprehensif dalam memberikan perawatan. Komprehensif artinya dalam memenuhi kebutuhan dasar pasien, tidak hanya berfokus pada pemenuhan fisiologis dan psikologisnya, tetapi seluruh aspek yang menjadi dampak dari keluhan yang dirasakan oleh pasien (Iyus, 2009).

Hasil analisa bivariat antara tanggung jawab perawat terhadap kepuasan pasien dari hasil uji regresi, nilai $\mathrm{p}$ value pada kolom signifikan, didapatkan nilai $0.000 \quad(p<0.05), \quad$ menjelaskan bahwa terdapat hubungan antara tanggungjawab perawat terhadap kepuasan pasien.

Hasil ini sesuai dengan penelitian Sari \& Saraswati (2013) yang menyebutkan bahwa dokter, perawat, farmasi memiliki peranan yang penting dalam menentukan kualitas layanan rumah sakit. Ketiga jenis sumber daya ini menjadi inti pokok dalam proses pelayanan di rumah sakit, karena ketiga hal tersebut berhubungan langsung dengan kesembuhan pasien. Dokter bertanggung jawab terhadap pengobatan, perawat bertanggungjawab penuh terhadap perawatan pasien dan farmasi bertanggung jawab terhadap persediaan obat.

Kualitas proses pelayanan dalam rumah sakit melalui kepuasan pasien yang meliputi kualitas proses pelayanan oleh dokter, perawat, staf farmasi dan administrasi. Penelitian ini menemukan bahwa kualitas proses pelayanan dokter dan perawat berdampak terhadap kepuasan pasien, sedangkan kualitas proses pelayanan oleh staf farmasi dan kemudahan adminitratif tidak berdampak terhadap kepuasan pasien (Sari \& Saraswati, 2013).

Padma, et al. (2010) menemukan bahwa secara simultan dimensi kualitas pelayanan berdampak terhadap kepuasan, sedangkan pengujian secara parsial dimensi kualitas layanan (kualitas personal, perawatan klinis, image dan kepercayaan pada rumah sakit) berdampak terhadap kepuasan pasien, sedangkan dimensi kualitas layanan yang tidak berdampak terhadap kepuasan pasien adalah kualitas infrastruktur, prosedur administrasi, keselamatan, dan tanggung jawab sosial.

2. Analisis Mengenal Perilaku Pasien terhadap kepuasan pasien di Ruang Perawatan Kritis IGD dan ICU RSUD Kabupaten Pangkajene dan Kepulauan

Hasil penelitian mengenai sejauh mana perawat mengenal perilaku pasien di ruang perawatan kritis IGD dan ICU RSUD Kabupaten Pangkajene dan Kepulauan, menjelaskan bahwa dalam memberikan asuhan keperawatan, perawat mengenal perilaku pasien terlebih dahulu sebesar 68.99\% melaksanakan dengan baik, dan sebesar $31.01 \%$ melaksanakan dengan cukup baik. Hal ini menjelaskan bahwa perawat di ruang perawatan kritis sebagian besar telah memahami dan melaksanakan tahapan dari pengkajian keperawatan dengan cara mengenal perilaku pasien terlebih dahulu sebelum penegakan diagnosa keperawatan, dengan cara mengenal respon pasien terhadap nyeri, kenyamanan, status nutrisi, status eliminasi dan respon biopsikososial dan spiritual lainnya yang merupakan keluhan yang dirasakan oleh pasien. 
Perawat harus memandang pasien sebagai manusia yang utuh dan unik. Utuh artinya seluruh pasien memiliki kebutuhan dasar yang kompleks dan saling berkaitan antara kebutuhan yang satu dengan yang lainnya. Unik artinya setiap individu bersifat khas dan tidak bisa disamakan dengan individu lainnya, sehingga memerlukan pendekatan khusus, dengan lebih mengenal pasien dari perilakunya, dari riwayatnya seperti riwayat kelahiran, riwayat masa anak, pendidikan, hobby, pola asuh, lingkungan, pengalaman traumatik dan cita-cita yang berbeda. Kemampuan perawat dalam memahami perilaku dan riwayat pasien dikenal dengan Ability to know Life span History secara holistik.

Hasil analisa bivariat antara mengenal perilaku pasien terhadap kepuasan pasien dari hasil uji regresi, nilai $\mathrm{p}$ value pada kolom signifikan, didapatkan nilai $0.000(\mathrm{p}<0.05)$, menjelaskan bahwa terdapat hubungan antara mengenal perilaku pasien terhadap kepuasan pasien.

Hasil ini sesuai dengan penelitian oleh Tutu dan NurAini (2018), yang menjelaskan bahwa perawat merupakan ujung tombak pelayanan kesehatan. Puas atau tidaknya pasien terhadap pelayanan kesehatan merupakan indikator dan salah satu faktor penentu baik buruknya kualitaspelayanan keperawatan. Perawat yang profesional dan berkualitas harus memiliki ketrampilanhard skill dan soft skill. Ketrampilan soft skill meliputi kemampuan untuk berkomunikasi, empati dan caring. Caring merupakan suatu sikap peduli, hormat dan menghargai orang lain. Faktanyabanyak perawat yang belum mencerminkan perilaku caring dalam memberikan asuhan keperawatan kepada klien. Tujuan penelitian ini adalah memberikan intervensi berupa komunikasi terapeutik untuk mengembangkan atau meningkatkan perilaku caring perawat sehingga hal ini akan berdampak pada mutu layanan keperawatan \& kepuasan pasien. Hasil yang didapatkan adalah terdapat peningkatan perilaku caring perawat terutama dalam komunikasi yang terpeutik dan peningkatan kepuasan pasien setelah diberikannya asuhan keperawatan oleh perawat yang telah mendapatkan pelatihan perilaku caring. Caring perawat dapat diimplementasikan ke dalam tahapan asuhan keperawatan yaitu mengenal perilaku pasien yang dirawat.

3. Reaksi Segera dari Perawat terhadap kepuasan pasien di Ruang Perawatan Kritis IGD dan ICU RSUD Kabupaten Pangkajene dan Kepulauan

Hasil penelitian mengenai sejauh mana reaksi segera perawat terhadap kepuasan pasien di ruang perawatan kritis IGD dan ICU RSUD Kabupaten Pangkajene dan Kepulauan, menjelaskan bahwa perawat yang memberikan reaksi segera dengan baik sebanyak $56.59 \%$, dan berespon dengan cukup baik sebesar 43.41\%. Dari data tersebut, dapat dijelaskan bahwa perawat di IGD dan ICU memiliki reaksi segera atau respon time yang sebagian besar baik, dimana perawat dalam melakukan tindakan keperawatan segera, menggunakan waktu rata-rata $\leq 5$ menit. Respons time merupakan waktu tanggap perawat dalam memberikan tindakan segera kepada pasien. Waktu tanggap yang baik bagi pasien yaitu $<5$ menit

Perawat adalah suatu profesi yang mempunyai fungsi autonomi yang didefinisikan sebagai fungsi profesional keperawatan.Fungsi profesional yaitu membantu mengenali dan menemukan kebutuhan pasien yang bersifat segera.Itu merupakan tanggung jawab perawat untuk mengetahui kebutuhan pasien dan 
membantu memenuhinya (Schmieding, 1993).

Hasil analisa bivariat antara rekasi segera perawat terhadap kepuasan pasien dari hasil uji regresi, nilai $\mathrm{p}$ value pada kolom signifikan, didapatkan nilai 0.000 $(\mathrm{p}<0.05)$, menjelaskan bahwa terdapat hubungan antara reaksi segera perawat terhadap kepuasan pasien.

Hasil ini sejalan dengan penelitian yang dilakukan oleh Rembet, dkk (2015) yang menjelaskan bahwa kepercayaan pasien kepada perawat lebih mudah untuk tumbuh di antara orang-orang yang memiliki kepentingan dan tujuan yang sama, sehingga lebih mudah untuk mengubah kepercayaan individu dari pada mengubah kepercayaan suatu kelompok, penelitian ini menganalisis hubungan Response Time Perawat dengan Tingkat Kepercayaan Keluarga Pasien di Instalasi Gawat Darurat RSU GMIM Kalooran Amurang, hasil penelitian dengan menggunakan uji chi-square diperoleh nilai $\mathrm{p}$ value $=0,008(<0,05)$. Yang menjelaskan bahwa terdapat hubungan yang signifikan antara response time perawat dengan tingkat kepercayaan keluarga pasien di Instalasi Gawat Darurat RSU GMIM Kalooran Amurang, dengan tumbuhnya kepercayaan dari keluarga pasien, maka hal ini akan memberikan kepuasan tersendiri pada pasien dan keluarga yang telah mendapatkan pelayanan dengan baik oleh perawat.

Selain itu, Pisu, dkk (2015), menjelaskan hasil penelitiannyatentang adanya hubungan antara respons time perawat dengan kepuasan pasien. Kategori yang digunakan yaitu kategori respons time cepat dan puas, didapatkan sebanyak 19 orang $(51,4 \%), 11$ orang kurang puas $(29,7 \%)$, sedangkan yang tidak puas 7 orang $(18,9)$ sedangkan respons time lambat tidak puas $10(43,5 \%)$, kurang puas 9 orang $(39,1 \%)$, dan puas 4 orang $(17,4 \%)$, sehingga dapat disimpulkan bahwa penelitian ini menjelaskan terdapat hubungan yang bermakna antara respons time perawat dengan kepuasan pasien, semakin cepat respons time perawat semakin puas pasien, dan sebaliknya semakin lambat respons time perawat, maka pasien akan semakin tidak puas.

Persepsi, berfikir, dan merasakan terjadi secara otomatis dan hampir simultan.Oleh karena itu perawat harus belajar mengidentifikasi setiap bagian dari reaksinya. Hal ini akan membantu dalam menganalisis reaksi yang menentukan mengapa perawat harus berespon segera. Perawat harus dapat menggunakan reaksinya untuk membantu pasien (Tomey, 2006).

Berdasarkan Pedoman Depkes, (1990), menyebutkan bahwa kompetensi yang harus dimiliki oleh perawat di ruang perawatan kritis adalah kemampuan perawat dalam membuka dan membebaskan jalan nafas (airway), kemampuan memberikan ventilator (breathing), kemampuan melakukan resusitasi jantung paru, kemampuan menghentikan perdarahan, kemampuan balut bidai dan transportasi, kemampuan mengenal dan menggunakan obat resusitasi dan kemampuan melakukan perekaman dan membaca hasil EKG pasien.

4. Disiplin dalam proses keperawatan terhadap kepuasan pasien di Ruang Perawatan Kritis IGD dan ICU RSUD Kabupaten Pangkajene dan Kepulauan

Hasil penelitian mengenai sejauh mana disiplin dalam asuhan keperawatan, yang menjelaskan tentang disiplin dalam pendokumentasian asuhan keperawatan oleh perawat di ruang perawatan kritis IGD dan ICU RSUD Kabupaten Pangkajene dan 
Kepulauan yaitu sebagian besar perawat telah melaksanakan disiplin dalam asuhan keperawatan dengan baik sebesar $56.59 \%$ dan sebesar $43.41 \%$ dengan cukup baik. Hal ini membuktikan bahwa perawat di IGD dan ICU RSUD Kabupaten Pangkajene dan Kepulauan, telah melaksanakan pendokumentasian asuhan keperawatan dengan baik, namun masih terdapat perawat yang belum disiplin dalam pelaksanaannya, hal ini dapat disebabkan oleh faktor banyaknya pasien yang ditangani pada saat jaga, pasien yang masuk membutuhkan tindakan secara maksimal/total, sehingga waktu untuk mendokumentasikan asuhan keperawatan menjadi berkurang.

Menurut George (1995), disiplin dalam proses keperawatan merupakan interaksi total (totally interactive) yang dilakukan tahap demi tahap, apa yang terjadi antara perawat dan pasien dalam hubungan tertentu, perilaku pasien, reaksi perawat terhadap perilaku tersebut dan tindakan yang harus dilakukan, mengidentifikasi kebutuhan pasien untuk membantunya serta untuk melakukan tidakan yang tepat, sehingga apabila perawat dapat melaksanakan tindakan dengan baik, maka pasien akan turut merasakan manfaatnya.

Berdasarkan hasil uji regresi, menjelaskan bahwa hasil nilai $\mathrm{p}$ value pada kolom signifikan, didapatkan nilai 0.000 , $(\mathrm{p}<0.05)$ yang menunjukkan adanya hubungan yang signifikan antara disiplin dalam keperawatan terhadap kepuasan pasien. Semakin disiplin perawat dalam melaksanakan asuhan keperawatan dengan baik, maka pasien akan merasakan manfaat yang sangat besar.

Hasil ini sejalan dengan penelitian yang telah dilakukan oleh Tamaka, dkk (2015), yang menghubungkan antara beban kerja dengan pendokumentasian asuhan keperawatan, hasil uji beban kerja dengan pendokumentasian asuhan keperawatan di dapatkan nilai $\mathrm{p}$ value $=0,008$, menjelaskan bahwa terdapat hubungan beban kerja dengan pendokumentasian di Instalasi Gawat Darurat Medik RSUP. Prof. Dr. R.D Kandou Manado, sehingga penelitian ini mendukung variabel independent perawat di RSUD Kabupaten Pangkajene dan Kepulauan yang masih mendokumentasikan asuhan keperawatan kurang lengkap/cukup baik sebesar $43.41 \%$ akibat beban kerja di perawatan kritis yang tinggi, dimana rata-rata pasien masuk sebanyak 35 pasien per hari. Jika dihubungkan dengan kepuasan pasien, maka hubungan yang paling lemah adalah variabel disiplin dalam asuhan keperawatan dibanding variabel lainnya, dimana pasien tidak memiliki persepsi yang cukup untuk dapat menilai kedisiplinan perawat dalam mendokumentasikan asuhan keperawatan di ruangan, namun tetap memiliki hubungan yang signifikan dimana jika perawat semakin disiplin dalam pendokumentasian askep, maka perkembangan pasien setai saat akan dapat diukur oleh perawat tersebut, sehingga akan berdampak pada kepuasan pasien terhadap pelayanan perawat.

Disiplin proses keperawatan meliputi komunikasi perawat kepada pasiennya yang sifatnya segera, mengidentifikasi permasalahan klien yang disampaikan kepada perawat, menanyakan untuk validasi atau perbaikan. Disiplin proses keperawatan didasarkan pada "proses bagaimana seseorang bertindak". Tujuan dari proses disiplin ketika digunakan antara perawat dan pasien adalah untuk membantu pemenuhan kebutuhan pasien. Peningkatan perilaku positif dari pasien merupakan indikasi dari 
pemenuhan kebutuhan sebagai hasil yang diharapkan.(Tomey, 2006).

5. Kemajuan/peningkatan kondisi pasien terhadap kepuasan pasien di Ruang Perawatan Kritis IGD dan ICU RSUD Kabupaten Pangkajene dan Kepulauan

Hasil penelitian mengenai sejauh mana perawat mengevaluasi kemajuan kondisi pasien dan hubungannya dengan kepuasan pasien, yaitu terdapat perilaku perawat yang mengevaluasi kemajuan kondisi pasien dengan baik sebesar $90.70 \%$ dan cukup baik sebesar $9.30 \%$. Hal ini menjelaskan bahwa kepedulian perawat untuk mengevaluasi kemajuan kondisi pasien setelah dilakukan tindakan keperawatan, sudah sangat baik, meskipun masih ada beberapa perawat yang frekuensi evaluasinya terhadap pasien masih kurang, karena beberapa faktor seperti dalam kerja tim, terkadang masing menggunakan metode fungsional, dimana perawat ada yang bertugas untuk meng-anamnesa, ada yang bertugas untuk memberikan tindakan mandiri dan ada pula yang bertugas untuk mengobservasi setelah perawat yang lainnya melakukan tindakan ke pasien tersebut, sehingga perawat yang fokusnya bertugas mengevaluasi, akan mendapat penilaian lebih baik dibandingkan perawat yang tidak ditugaskan untuk mengevaluasi.

Namun, perawat harus dipandang sebagai perawat secara utuh, yang mampu mengidentifikasi kemajuan dari kondisi pasien, yang memiliki nilai kritis dan nilai empati yang lebih baik karena mampu mengevaluasi kemajuan pasien yang dirawatnya. Evaluasi pada fase tindakan proses disiplin merupakan hal yang tidak dapat dipisahkan. Tindakan-tindakan yang terencana, setelah tindakan lengkap dilaksanakan, perawat harus mengevaluasi keberhasilannya. Evaluasi asuhan keperawatan difokuskan terhadap perubahan perilaku pasien terhadap kemampuan menolong dirinya untuk mengatasi ketidakmampuannya. Evaluasi dilakukan setelah tindakan keperawatan dilaksanakan (Nursalam, 2001).

Menurut Wilkinson (2007) dalam Rohmah (2012), menjelaskan bahwa dalam proses keperawatan, evaluasi adalah suatu aktivitas yang direncanakan secara terus menerus, merupakan aktivitas yang disengaja dan sistematik untu menilai kualitas pelayanan yang diberikan dibandingkan dengan standar asuhan yang ada.

Berdasarkan hasil uji regresi, menjelaskan bahwa hasil nilai $\mathrm{p}$ value pada kolom signifikan, didapatkan nilai 0.000 $(\mathrm{p}<0.05)$ yang menunjukkan adanya hubungan yang signifikan antara evaluasi kemajuan kondisi pasien terhadap kepuasan pasien.

Hasil ini sejalan dengan penelitian yang dilakukan oleh Nurhidayah (2014) yang menjelaskan bahwa evaluasi kemajuan kondisi pasien merupakan salah satu tahapan dari proses asuhan keperawatan terhadap pasien, dimana proses asuhan keperawatan merupakan salah satu faktor yang berpengaruh terhadap kepuasan pasien di Rumah Sakit. Hasil analisis menun-jukkan bahwa Asuhan Keperawatan terhadap pasien berbanding lurus dengan peningkatan mutu pelayanan kesehatan serta kepuasan pasien di Rumah Sakit

\section{DAFTAR PUSTAKA}

Afriani N, (2012), Analisis Penanganan Keluhan Pelanggan Oleh Instalasi Pemasaran dan Humas RSUP Fatmawati Jakarta, diakses dari : lib.ui.ac.id/file?file = digital/20320382S-Nurul\%20Afriani.pdf 
Badan Pengembangan Pemberdayaan Sumber Daya Manusia Kesehatan, Kemenkes RI, (2017), Data Jumlah Tenaga Perawat di Indonesia.

Dahlan, S. (2014). Statistik Untuk Kedokteran Dan Kesehatan: Deskriptif, Bivariat, dan Multivariat Dilengkapi Aplikasi Menggunakan SPSS. Jakarta: Epidemiologi Indonesia.

Dempsey, P. A. \& Dempsey, A. D. (2002). Riset Keperawatan: Buku Ajar dan Latihan. Edisi 4. Jakarta: EGC.

Dharma, K. K. (2011). Metode Penelitian Keperawatan, Panduan Melaksanakan dan Menerapkan Hasil Penelitian. Jakarta: Trans Info Media.

Donabedian, (1988), The Quality Of Care, Archives of Pathology \& Laboratory Medicine; Nov 1997; 121, 11; ProQuest Nursing Journals pg. 1145

Emanuel, (2008), Analisis Faktor-Faktor Yang Mempengaruhi Kinerja Klinis Perawat Berdasarkan Penerapan Sistem Pengembangan Manajemen Kinerja Klinis (SPMKK) Di Ruang Rawat Inap Rumah Sakit Panti Wilasa Citarum Semarang.

Fitria, Stefanus, (2014), Analisis Kualitas Pelayanan Menurut Brady and Cronin di Poli Anak, Jurnal Administrasi Kesehatan Indonesia Vol.2 No.1.

Hariyanti \& Primawestri, I. (2010). Pengaruh Komunikasi Dan Motivasi Kerja Terhadap Kinerja Perawat Dengan Komitmen Organisasi Sebagai Variabel Moderating (Studi Kasus pada Instalasi Rawat Inap Rumah Sakit Umum Daerah Karanganyar). Diakses dari download.portalgaruda.org/article.ph p? article $=90193 \&$ val $=4283$
Hariyati, R. T. S. (2014). Pengembangan Dan Utilisasi Tenaga Keperawatan. Jakarta: Rajawali Press.

Harris, O. J. \& Hartman, S., J. (2002). Organizational Behaviour. New York: An Imprint Of The Haworth Press Inc.

Hasan M, (2016), Analisis Pengaruh Kualitas Pelayanan Terhadap Kepuasan Pasien Pada Rumah Sakit Umum Daerah Sukoharjo, diakses dari Https://Www.Academia.Edu/3671619 2/Analisis_Pengaruh_Kualitas_Pelaya nan_Terhadap_Kepuasan_Pasien_Pada _Rumah_Sakit_Umum_Daerah_Sukoh arjo

Hastono, S. P. (2014). Analisa Data Kesehatan. Depok: FKM-UI.

Huber, D. L. (2010). Leadership and Nursing Care Management Fourth Edition. Missouri, USA: Saunders Elsevier.

Ivancevich, J. M., Konopaske, R., \& Matteson, M. T. (2007). Perilaku Dan Manajemen Organisasi. Jakarta: Erlangga.

James D. Vail, M.-E. J. (1986). Quality Assurance: The Pieces of The Puzzle. Journal Of the Association of Nurse Anasthetists.

Kalalo, C. N., Sjattar, E. L., \& Natzir, R. (2015). Correlation Between Compensation And Work Satisfaction And Nurses' Performance Through Motivation In Inpatient Room Of Bethesda Public Hospital Of Tomohon. Diakses dari pasca.unhas.ac.id/jurnal/files/fb0368a 4d5efbf66eabfe 17448f31f7e.pdf

Kementerian Kesehatan RI, (2008), Standar Pelayanan Minimal Rumah Sakit Nomor 129 Tahun 2008. 
Kementerian Kesehatan RI, Pusat Data dan Informasi, (2017), Situasi Tenaga Keperawatan Indonesia, Jakarta Selatan

Keputusan Menteri Pendayagunaan Aparatur Negara Nomor 25 Tahun 2004 tentang Pedoman Umum Penyusunan Indeks Kepuasan Masyarakat Unit Pelayanan Instansi Pemerintah

Knights, D. \& Willmott, H. (2007). Introducing Organizational Behaviour And Management. London: Thomson Learning.

Luthans, F. (2011). Organizational Behaviour: An Evidence Based Approach. 12 ${ }^{\text {th }}$ edition. New York: McGraw Hill Inc.

Mangole, Josua, Rompas, Sefty, Amatus, (2015), Hubungan Perilaku Perawat dengan Pendokumentasian Asuhan Keperawatan di Cardiovaskular and Brain Center RSUP Prof. Dr. R. D. Kandou Manado, Vol.3 No.2, diakses dari

http://id.portalgaruda.org/index.php?re $\mathrm{f}=$ browse \& mod=viewarticle \&article $=3$ 78273

Marquis \& Houston (2003), Kepemimpinan dan Manajemen Keperawatan, EGC : Jakarta

Marquis, B. L. \& Huston, C. J. (2009). Leadership Roles And Management Functions in Nursing: Theory And Application. $6^{\text {th }}$ Edition. Philadelphia: Lippincott Williams \& Wilkins.

McEwen, M. \& Wills E. M. (2011). Theoretical Basis For Nursing. $3^{\text {rd }}$ edition. China: Lippincott Williams \& Wilkins.

Mei F., Ahmad, (2018), Hubungan Pelaksanaan Tindakan Keperawatan
Berdasarkan Kebutuhan Dasar Manusia Virginia Handerson dengan Kepuasan Pasien di RS Bhayangkara Wahyu Tutuko Bojonegoro, Journal of Health Sciences, Vol. 11 No. 2, August 2018, 140-150

Mustofa, (2008), Hubungan Antara Persepsi Pasien terhadap Dimensi Mutu Pelayanan Keperawatan dengan Kepuasan Pasien di Ruang Rawat Inap RSU Muhammadiyah Tumanggung Semarang, Jurnal Keperawatan Vol.1 No. 2

Naser, Rima Wahyu, Mulyadi, Reginus, (2015), Hubungan Faktor-Faktor Eksternal dengan Response Time Perawat dalam Penanganan Pasien Gawat Darurat di IGD RSUP Prof. Dr. R. D. Kandou Manado, Vol.3 No.2, diakses dari : http://id.portalgaruda.org/index.php?re $\mathrm{f}=$ browse \&mod $=$ viewarticle \&article $=3$ 31789

Notoatmodjo, S. (2012). Metodologi Penelitian Kesehatan. Jakarta: Rineka Cipta.

Nurhidayah, (2014), Manajemen Model Asuhan Keperawatan Profesional (MAKP) Tim Dalam Peningkatan Kepuasan Pasien Di Rumah Sakit, diakses dari : https://www.ejurnal.com/2016/11/manajemenmodel-asuhan-keperawatan.html

Nurjannah, Intansari, (2010), Proses Keperawatan NANDA, NOC \& NIC, Yogyakarta : Mocomedika.

Nursalam, (2008), Proses dan Dokumentasi Keperawatan Konsep dan Praktik, Jakarta : Salemba Medika

Nursalam, (2016), Manajemen Keperawatan, Jakarta : Salemba Medika 
Parwita, G. B. S. (2013). Pengaruh Kepuasan Kerja Terhadap Komitmen Organisasi Dan Disiplin Kerja.

Peraturan Menteri Kesehatan Nomor 11 tahun 2017 tentang Keselamatan Pasien Rumah Sakit

Peraturan Menteri Pemberdayaan Aparatur Negara dan Reformasi Birokrasi No. 16 Tahun 2014 tentang Pedoman Survey Kepuasan Masyarakat terhadap Penyelenggaraan Pelayanan Publik

Peraturan Menteri Pemberdayaan Aparatur Negara dan Reformasi Birokrasi No. 14 Tahun 2017 tentang Pedoman Penyusunan Survey Kepuasan Masyarakat Unit Penyelenggaraan Pelayanan Publik

Persatuan Perawat Nasional Indonesia (2014). Kode Etik. Diakses dari http://www.inna-

ppni.or.id/index.php/kode-etik

Pisu, Hermawan, Rompas, (2015), Hubungan Respons Time Perawat dengan Kepuasan Pasien di Instalasi Gawat Darurat RSUP Prof. Dr. R. D. Kandou Manado, Vol.3 No.2, diakses dari

http://id.portalgaruda.org/index.php?re $\mathrm{f}=$ browse $\& \bmod =$ viewarticle $\&$ article $=3$ 78325

Polit, D.F., \& Beck, C.T. (2012). Nursing Research, Generating And Assesing Evidence For Nursing Practice $\left(9^{\text {th }} e d\right)$. China: Lippincot Williams \&Wilkins.

Presiden Republik Indonesia (2009). Undang-Undang Republik Indonesia Nomor 36 Tahun 2009 Tentang Kesehatan. Diakses dari http://peraturan.go.id/uu/nomor-36tahun-2009.html
Presiden Republik Indonesia (2009). Undang-Undang Republik Indonesia Nomor 44 Tahun 2009 Tentang Rumah Skait. Diakses dari http://peraturan.go.id/uu/nomor-44tahun-2009.html

Presiden Republik Indonesia (2014). Undang-Undang Republik Indonesia Nomor 38 Tahun 2014 Tentang Keperawatan. Diakses dari http://www.hukor.depkes.go.id/up_pro d_uu/UU\%20No.\%2038\%20Th\%2020 14\%20ttg\%20Keperawatan.pdf

Prihandhani, I. G. A. A. S. (2015). Hubungan Faktor Individu Dan Budaya Organisasi Dengan Perilaku Caring Perawat Pelaksana Di Ruang Rawat Inap Rumah Sakit Umum Ganesha Gianyar. Diakses dari erepo.unud.ac.id/4642/1/e93260e75afa b2b465f943d06c578e5e.pdf

Rahardiantini, (2012), Hubungan Komunikasi Terapeutik Keperawatan terhadap Kepuasan Pasien di RS, Vol.2 No.1, Jurnal Keperawatan Stikes Hangtuah

Rahayu, F. D. (2012). Hubungan Antara Budaya Organisasi Dengan Komitmen Organisasi Pada Perawat Rumah Sakit Umum Daerah Dr. Syaiful Anwar Malang. Jurnal Psikologi Agustus 2012, Vol. 1, No. 2.

Rebeiro, G., Jack, L., Scully, N., \& Wilson, D. (2015). Keperawatan Dasar: Manual Keterampilan Klinis. Singapore: Elsevier.

Rembet, Mario Alan, Mulyadi, Malara, Reginus (2015), Hubungan Response Time Perawat Dengan Tingkat Kepercayaan Keluarga Pasien Pada Triase Kuning (Urgent) Di Instalasi Gawat Darurat RSU GMIM Kalooran Amurang. Jurnal Keperawatan, Volume 3 Nomor 2. Diakses dari : 
http://id.portalgaruda.org/index.php?re $\mathrm{f}=$ browse \& $\bmod =$ viewarticle $\&$ article $=3$ 78294

Robbins, S. P. \& Judge, T. A. (2013). Perilaku Organisasi Edisi 12. Jakarta: Salemba Empat.

Rudianti, Y. (2011). Hubungan Komunikasi Organisasi Dengan Kinerja Perawat Pelaksana Di Ruang Rawat Inap Rumah Sakit Swasta Surabaya.Diakses dari

http://lib.ui.ac.id/file?file=digital/2028

2765-T\%20Yulistia

na\%20Rudianti.pdf

Sastroasmoro, S., \& Ismael, S. (2014). Dasar-Dasar Metodologi Penelitian Klinis, Edisi 5. Jakarta: Sagung Seto.

Sitorus, R. \& Panjaitan, R. (2011). Manajemen Keperawatan: Manajemen Keperawatan Di Ruang Rawat. Jakarta: Sagung Seto

Sugiyono (2013). Metode Penelitian Kuantitatif, Kualitatif Dan $R \& D$. Bandung: Alfabeta.

Sundari, M. N. D. (2014). Kualitas Pelayanan Kesehatan Di RSUP Sanglah Denpasar Dari Perspektif Pelanggan Internal Dan Eksternal. Diakses dari http://www.pps.unud.ac.id/thesis/pdf t hesis/unud-1083-1388655567tesis\%20lengkap\%20cd.pdf

Tamaka, Ryny, Mulyadi, Reginus, (2015), Hubungan Beban Kerja dengan Pendokumentasian Asuhan Keperawatan di Instalasi Gawat Darurat Medik Rsup. Prof. Dr. R.D Kandou Manado, Vol.3, No.2, diakses dari

http://id.portalgaruda.org/index.php?re $\mathrm{f}=$ browse \&mod=viewarticle $\&$ article $=3$ $\underline{31827}$
Tribowo, C. (2013). Manajemen Pelayanan Keperawatan Di Rumah Sakit. Jakarta: Trans Info Media.

Wahyuningsih, S. (2013). Kepercayaan Dan Pengambilan Keputusan Terhadap Kinerja Perawat. $2^{\text {nd }}$ International Seminar on Quality and Affordable Education. Diakses dari educ.utm.my/wpcontent/uploads/2013/11/43.pdf

Wijaya H, (2012), Analisis Pelaksanaan Standar Pelayanan Minimal Farmasi di Instalasi Farmasi RS Tugu Ibu Depok.

World Health Organization (2012). Health Education: Theoretical Concepts, Effective Strategies and Core Competencies. Diakses dari: apps.who.int/iris/bitstream/10665/1199 53/1/EMRPUB_2012_EN_1362.pdf

Yosafianti, V. \& Alfiyanti, D. (2010). Pengaruh Pendidikan Kesehatan Persiapan Pasien Pulang Terhadap Kepuasan Pasien Tentang Pelayanan Keperawatan Di RS Romani Semarang. Diakses dari: http://jurnal.unimus.ac.id/index.php/ps n12012010/article/view/55

Yosep Iyus. (2009). Tanggung Jawab dan Tanggung Gugat dalam Sudut Pandang Etik, diakses dari http://stikes.file.wordpress/2009 